Egyptian Journal of Aquatic Biology \& Fisheries

Zoology Department, Faculty of Science,

Ain Shams University, Cairo, Egypt.

ISSN $1110-6131$

Vol. 24(5): $563-587$ (2020)

www.ejabf.journals.ekb.eg

\title{
Mesozooplankton dynamics in the coastal waters of Sharm El-Sheikh, Red Sea, Egypt
}

\author{
Mohsen El-Sherbiny ${ }^{1,2}$, Mahmoud Hanafy ${ }^{2}$, Mohamed Dorgham ${ }^{3}$ \\ ${ }^{1}$ Department of Marine Biology, Faculty of Marine Sciences, King Abdul Aziz University, \\ Jeddah, Saudi Arabia \\ ${ }^{2}$ Department of Marine Sciences, Faculty of Science, Suez Canal University, Ismailia, Egypt \\ ${ }^{3}$ Department of Oceanography, Faculty of Science, Alexandria University, Alexandria, Egypt \\ * Corresponding author: mdorgham1947@yahoo.com
}

\begin{abstract}
ARTICLE INFO
Article History:

Online: Aug. 25, 2020

Keywords:

Zooplankton,

copepods,

Sharm El-Sheikh,

Red Sea
\end{abstract}

Received: July 30, 2020

Accepted: Aug. 19, 2020

\begin{abstract}
The zooplankton community was studied monthly in shallow embayments around Sharm El-Sheikh, northern Red Sea, in relation to physical chemical properties. The study recorded a total of 91 species, amounting monthly to $2169-12319$ ind. $/ \mathrm{m}^{3}$ in the whole area and $3382-7835 \mathrm{ind} . / \mathrm{m}^{3}$ at the sampling sites. Copepods were the most diverse group represented by 68 species, with clear species diversity of calanoids (48), and less so for cyclopoids (13) and harpacticoids (7). Copepods constituted $68.2 \%$ of the total zooplankton count. Thirty two species were persistent in the whole area, including 28 copepods, while all other zooplankton groups were pronouncedly less diversified. Among these groups larvaceans formed $3.1 \%$ and cladocerans $(2.1 \%)$. The meroplankton representatives played crucial role, forming $23.7 \%$ of the zooplankton count. The Bray-Curtis analysis demonstrated high similarity between sites I, III and IV. Eleven epipelagic, mesopelagic, or bathypelagic forms were recorded in the shallow waters of Sharm El-Sheikh, indicating the effect of winter vertical mixing on zooplankton distribution.
\end{abstract}

\section{INTRODUCTION}

The zooplankton play important roles in marine biogeochemical cycles and food webs, as they act as a link for the energy transfer from lower to higher trophic levels and have a key role in the recycling and mediating of macronutrients (Stibor et al., 2004; Turner, 2004; Mitra et al., 2014a,b). During the past three decades the Egyptian coast of the Red Sea and the Gulf of Aqaba, including Sharm El-Sheikh has been exposed to intensive human activities, which exhibited pronounced effects on the topography, environmental characteristics and the biotic components of these regions. Numerous studies were carried out on the zooplankton of the Red Sea, either on the spatial distributions of the major 
mesozooplankton groups or on specific taxa. Some studies were dealt with mesozooplankton populations along longitudinal axis of the Red Sea (e.g. Delalo, 1966; Gordeyeva, 1970; Pearman and Irigoien, 2015; Kürten et al., 2015; Al-Aidaroos et al., 2016; Casas et al., 2017), on the Gulf of Aqaba (Almeida Prado-Por, 1983; Bottger-Schnack et al., 2001; Cornils et al., 2005; Mantha et al., 2019). The seasonal structure of zooplankton was followed in the offshore of the northern Gulf of Aqaba (e.g. Echelman and Fishelson, 1990; Al-Najjar et al., 2002; Cornils et al., 2007b), along its Egyptian coast (Khalil and Adel-Rahman, 1997; El-Serehy et al., 2013), and southern part (Aamer et al., 2006; El-Sherbiny et al., 2007; Dorgham et al., 2012). Scarse studies were done on shallow water zooplankton of the Egyptian Red Sea coast, including that in mangrove swamp near Sharm El Sheikh (Hanafy et al., 1998) and in Hurghada (Abu El-Regal. et al., 2019).

The present study could be considered as the first one following the monthly qualitative quantitative dynamics of zooplankton community relative to the surrounding environmental conditions in the coastal water of Sharm El-Sheikh area, at the southern Gulf of Aqaba.

\section{MATERIALS AND METHODS}

\section{Sampling sites:}

The present study was carried out at three isolated coastal areas, including 4 sites with different environmental characteristics (Fig. 1), namely Naama Bay (site I), Sharm ElMaiya Bay (sites II and III) and Sharm El-Sheikh Bay (site IV). Naama Bay is located approximately $15 \mathrm{~km}$ south to the Strait of Tiran at $27^{\circ} 55^{\prime} \mathrm{N}$ and $34^{\circ} 20^{\prime} \mathrm{E}$, with a maximum depth of $100 \mathrm{~m}$ and exposed to touristic stress from a large number of tourist resorts, sailing and diving activities. Sharm El-Maiya Bay is a semi-enclosed bay lies at $27^{\circ} 51.8^{\prime} \mathrm{N}$ and $34^{\circ} 18.1^{\prime} \mathrm{E}$ and is divided into two water bodies, the small one is a nearshore subtidal area (site II) with $9 \mathrm{~m}$ depth. The large part of Sham El-Maiya Bay (site III) is pronouncedly deeper than the smaller one (maximum depth of $90 \mathrm{~m}$ ) and connected to it through an opening of $200 \mathrm{~m}$ width. Sharm El-Sheikh Bay (site IV) lies at the entrance of Sharm El-Sheikh City at $27^{\circ} 51^{\prime} \mathrm{N}$ and $34^{\circ} 16.7^{\prime} \mathrm{E}$, with a maximum depth of $35 \mathrm{~m}$ and very close to Sharm El-Maiya Bay, and is less stressed by human activities than the other sites.

\section{Sample collection:}

The hydrographic parameters (water temperature, salinity, $\mathrm{pH}$, dissolved oxygen), inorganic nutrients $\left(\mathrm{NO}^{3-}, \mathrm{NO}^{3-}, \mathrm{NH}^{4+}, \mathrm{PO}_{4}{ }^{-3}\right.$ and $\left.\mathrm{SiO}_{4}{ }^{4-}\right)$ and chlorophyll $a$ were measured monthly in water samples collected within the upper $50 \mathrm{~cm}$ of the surface water from March 1995 to February 1996. Water temperature was measured with an ordinary 
thermometer graduated to $0.1{ }^{\circ} \mathrm{C}$, salinity was determined argentometrically after APHA (1985). The $\mathrm{pH}$ was measured in situ with a digital $\mathrm{pH}$ meter (Jenway, model 3070) and dissolved oxygen (DO) and chlorophyll $a$ were determined following Parsons $\boldsymbol{e}$ t al. (1984), while inorganic nutrients were measured according to Strickland and Parsons (1972).

Zooplankton samples were collected by plankton net of $100 \mu \mathrm{m}$ mesh size and $40 \mathrm{~cm}$ mouth diameter (fitted with Hydro-Bios flow-meter) towed under the surface water behind a small boot at a fixed speed about 1-1.5 knot and the concentrated samples were preserved in $4 \%$ borax neutralized formalin solution. The zooplankton counting was undertaken in three aliquots of $5 \mathrm{ml}$ each of the concentrated sample in a Bogorov counting tray under a Hydro-Bios inverted microscope, and the standing crop was calculated from the average of the three counts. The identification of zooplankton taxa followed Giesbrecht (1892), Mori (1964), Heron and Bradford-Grieve (1995) and Conway et al. (2003).

\section{Statistical Analysis}

Analysis of variance was used to compare the total zooplankton between the sampling sites using Microsoft Excel statistical programme (2003). Duncan test and LSD test were used to show the significant differences between the four sites and twelve months in zooplankton using SPSS. Also p-value was calculated to determine the significance of the relationship between total plankton and physical and chemical parameters.

Quantification of the relation between total zooplankton and physical and chemical parameters was done by multiple regression analysis of the type:

$\mathrm{Y}=\mathrm{b}_{0}+\mathrm{b}_{1} \mathrm{X}_{1}+\mathrm{b}_{2} \mathrm{X}_{2}+\mathrm{b}_{3} \mathrm{X}_{3}+\mathrm{b}_{4} \mathrm{X}_{4}+\mathrm{b}_{5} \mathrm{X}_{5}+\mathrm{b}_{6} \mathrm{X}_{6}+\mathrm{b}_{7} \mathrm{X}_{7}+\mathrm{b}_{8} \mathrm{X}_{8}$

Where:

$\mathrm{Y}=$ Total Zooplankton, $\mathrm{X}_{1}=$ Water temperature $\left({ }^{\circ} \mathrm{C}\right), \mathrm{X}_{2}=$ Transparency, $\mathrm{X}_{3}=$ Salinity $(\%), X_{4}=\mathrm{pH}, \mathrm{X}_{5}=\mathrm{P}(\mathrm{mg} / \mathrm{L}), \mathrm{X}_{6}=\mathrm{NO}_{2}, \mathrm{X}_{7}=\mathrm{NO}_{3}, \mathrm{X}_{8}=\mathrm{O}_{2}$

\section{RESULTS}

\section{1-Environmental conditions}

The average surface water temperature in the study area fluctuated within the known seasonal range in the Egyptian Red Sea coast, between winter minimum $\left(22.7^{\circ} \mathrm{C}\right)$ in February and summer maximum $\left(30.6{ }^{\circ} \mathrm{C}\right.$ ) in August (Fig. 2A). Among the sampling sites, the monthly difference was mostly between 0.1 and $0.7{ }^{\circ} \mathrm{C}$, increased to $1.3-1.8^{\circ} \mathrm{C}$ in March, May, July and September. The surface salinity exhibited narrow variations over the whole area of study, varying monthly between $40.2 \%$ in March and $40.9 \%$ in August (Fig. 2B). The average pH values varied from 7.72 in April to 8.27 in February (Fig. 2C) with an average of $7.997 \pm 0.196$ for the entire study area. The average concentration of 
DO was $7.03 \pm 0.25 \mathrm{mg} / \mathrm{l}$, fluctuating between $6.73 \mathrm{mg} / \mathrm{l}$ in April and $7.35 \mathrm{mg} / \mathrm{l}$ in September (Fig. 2D). The saturation of DO amounted to 80-89\% most of the year, increased to $90-100 \%$ from August to October. The nutrients were mostly low in the whole area (Table 1), recording at the sampling sites $0.144-0.219 \mu \mathrm{M} / \mathrm{l}$ for phosphate, $0.206-0.435 \mu \mathrm{M} / 1$ for nitrate, $0.028-0.038 \mu \mathrm{M} / 1$ for nitrite, $0.88-1.15 \mu \mathrm{M} / 1$ for ammonia and $1.26-2.21 \mu \mathrm{M} / 1$ for silicate. On the time scale, phosphate displayed approximately similar monthly distribution at all the sampling sites, being low most of the year, except comparatively high values in March-May and October (Fig. 3a).

Table 1- The variation range of the measured parameters at the sampling sites.

\begin{tabular}{|l|l|l|l|l|}
\hline Parameter & I & II & III & IV \\
\hline Temp. & $25.61 \pm 2.6$ & $26.19 \pm 2.94$ & $25.81 \pm 2.9$ & $25.86 \pm 2.82$ \\
\hline Salinity & $40.48 \pm 0.28$ & $40.44 \pm 0.29$ & $40.48 \pm 0.28$ & $40.48 \pm 0.28$ \\
\hline pH & $7.96 \pm 0.16$ & $7.99 \pm 0.16$ & $8.00 \pm 0.31$ & $8.04 \pm 0.1$ \\
\hline $\mathrm{DO}$ & $6.99 \pm 0.31$ & $7.14 \pm 0.22$ & $7.0 \pm 0.21$ & $6.98 \pm 0.26$ \\
\hline $\mathrm{PO}_{4}$ & $0.219 \pm 0.22$ & $0.179 \pm 0.191$ & $0.144 \pm 0.174$ & $0.158 \pm 0.155$ \\
\hline $\mathrm{NH}_{4}$ & $1.06 \pm 1.0$ & $1.15 \pm 1.0$ & $0.97 \pm 0.83$ & $0.88 \pm 0.85$ \\
\hline $\mathrm{NO}_{2}$ & $0.03 \pm 0.036$ & $0.028 \pm 0.017$ & $0.038 \pm 0.037$ & $0.036 \pm 0.036$ \\
\hline $\mathrm{NO}_{3}$ & $0.34 \pm 0.21$ & $0.44 \pm 0.23$ & $0.41 \pm 0.33$ & $0.21 \pm 0.11$ \\
\hline $\mathrm{SiO}_{4}$ & $1.4 \pm 0.5$ & $2.21 \pm 1.18$ & $1.86 \pm 0.99$ & $1.26 \pm 0.53$ \\
\hline $\mathrm{Chl}_{\text {a }}$ & $0.48 \pm 0.74$ & $0.66 \pm 0.41$ & $0.37 \pm 0.48$ & $0.47 \pm 0.57$ \\
\hline
\end{tabular}

Nitrate demonstrated different monthly pattern, with high values in March and October at site I, in March, November and January at site II, in September, November and January at site III and in October site IV (Fig. 3b). Nitrite showed a small peak in April at site I, and in October at site II, three different peaks in April, August and November at site III, and two peaks in April and November at site IV (Fig. 3c). The ammonia exhibited irregular monthly variation at the most sampling sites, attaining high values from May to July, in addition to a peak in April at site I and in February at site II (Figure 3D). Silicate displayed three distinguished peaks in March, June-July and October-November at all studied sites (Figure 3e). The phytoplankton was generally poor, with biomass mostly lower than $1 \mu \mathrm{g}$ chl. $a / 1$, except the high value in September $(1.51-2.82 \mu \mathrm{g}$ chl. $a / \mathrm{l})$ (Fig. 3f).

\section{2-Zooplankton}

The surface zooplankton in Sharm EL-Sheikh comprised at least 91 species belonging to different phyla (Table 2). The number of species were comparatively higher at sites I and IV (83 and 85 respectively) than at sites II and III (68 and 75 respectively). The monthly number of species displayed wide fluctuation between $32-51$ at site I, 18 - 48 at site II, 19 - 43 at site III, and 24 - 51 at site IV. Thirty two species were found to be persistent (occurred more than 8 months) at one or more sites, but with considerably different abundances Table (2). 
Table 2. The timing of the maximum count of zooplankton species and groups and their frequency in months in the area of study $\left(\mathrm{Fr}=\right.$ number of months, $\mathrm{Ct}=$ count $\left(\right.$ ind. $\left.\mathrm{m}^{-3}\right), \mathrm{Mo}=$ Month of maximum count, $\mathrm{St}=$ site of maximum count, E: epipegaic, M: mesopalgic, EB: epi- to bathypelagic species, \#: persistent species)

\begin{tabular}{|c|c|c|c|c|c|c|c|c|c|}
\hline Species & Fr & $\mathbf{C t}$ & Mo & $\mathbf{S t}$ & Species & $\mathbf{F r}$ & $\mathbf{C t}$ & Mo & $\mathbf{S t}$ \\
\hline \multicolumn{5}{|l|}{ Calanoida } & Pontellina plumata & 7 & 1 & Feb & IV \\
\hline Acartia danae & 2 & 5 & Dec & III & Pontellopsis krameri & 3 & 1 & Nov & IV \\
\hline Acartia bispinosa \# & 12 & 3393 & May & I & $\begin{array}{l}\text { Phaenna spinifera } \\
\text { (EB) }\end{array}$ & 1 & 1 & Mar & I \\
\hline Acartia fossae \# & 12 & 385 & July & IV & $\begin{array}{l}\text { Pleuromamma } \\
\text { abdominalis (M) }\end{array}$ & 3 & 6 & Sep & III \\
\hline Acartia negligens \# & 12 & 128 & May & IV & Rhincalanus nasutus & 2 & 2 & Feb & $\mathrm{I}$ \\
\hline Acrocalanus gibber \# & 12 & 91 & Mar & & $\begin{array}{l}\text { Archescolecithrix } \\
\text { auropecten (EB) }\end{array}$ & 2 & 1 & Feb & IV \\
\hline Calanopia elliptica & 4 & 2 & Jan & III & $\begin{array}{l}\text { Macandrewella } \\
\text { chelipes Probably (M) }\end{array}$ & 2 & 1 & Nov & IV \\
\hline Calanopia media & 2 & 1 & Jan & IV & $\begin{array}{l}\text { Scolecitrichopsis } \\
\text { ctenopus ( E) }\end{array}$ & 1 & 1 & Apr & I \\
\hline Nannocalanus minor \# & 12 & 18 & May & IV & Temora stylifera \# & 8 & 6 & Oct & $\mathrm{I}$ \\
\hline Canthocalanus pauper & 7 & 16 & July & IV & Temora discaudata & 5 & 4 & Jul & IV \\
\hline Neocalanus robustior & 1 & 4 & Feb & II & Tortanus ampliramus \# & 10 & 6 & Feb & II \\
\hline Mesocalanus tenuicornis & 1 & 1 & Feb & IV & Tortanus recticauda & 1 & 1 & May & II \\
\hline Undinula vulgaris \# & 9 & 103 & Sept. & III & \multicolumn{5}{|l|}{ Cyclopoida } \\
\hline Calocalanus pavo \# & 12 & 21 & Nov & IV & Copilia mirabilis \# & 10 & 27 & Mar & I \\
\hline Calocalanus pavoninus & 3 & 5 & Feb & II & Farranula gibbula\# & 12 & 297 & Nov & III \\
\hline Calocalanus styliremis \# & 12 & 53 & Nov & IV & Corycaeus spp.\# & 12 & 195 & Mar & $\mathrm{I}$ \\
\hline Candacia bradyi & 1 & 1 & Oct & I & $\begin{array}{l}\text { Lubbockia squillimana } \\
\text { \# (M) }\end{array}$ & 10 & 11 & Aug & III \\
\hline Candacia catula & 7 & 6 & Jan & II & Oithona nana \# & 11 & 822 & Jun & II \\
\hline Candacia curta & 4 & 4 & Jan & I & Oithona plumifera \# & 12 & 103 & Feb & III \\
\hline Candacia truncate \# & 10 & 22 & Dec & $\mathrm{I}$ & Oithona spp. & 5 & 3 & Jan & II \\
\hline Centropages elongates \# & 12 & 65 & May & III & $\begin{array}{l}\text { Oncaea scottodicarloi } \\
\#\end{array}$ & 12 & 880 & Feb & II \\
\hline Centropages furcatus & 3 & 18 & Nov & I & $\begin{array}{l}\text { Oncaea mediterranea } \\
\#\end{array}$ & 12 & 781 & Apr & II \\
\hline Centropages gracilis & 4 & 6 & Feb & II & Triconia minuta & 2 & 3 & Dec & IV \\
\hline Centropages orsinii & 7 & 212 & July & III & Oncaea venusta & 5 & 5 & Dec & IV \\
\hline Ctenocalanus vanus \# & 8 & 19 & Apr & II & Oncaea sp. & 3 & 22 & May & II \\
\hline Centropages sp.\# & 9 & 21 & Jun & II & Sapphirina metallina & 4 & 6 & Sep & II \\
\hline $\begin{array}{l}\text { Clausocalanus } \\
\text { arcuicornis\# }\end{array}$ & 11 & 58 & Feb & IV & \multicolumn{5}{|l|}{ Harpacticoida } \\
\hline Clausocalanus furcatus \# & 12 & 994 & Mar & IV & $\begin{array}{l}\text { Clytemnestra } \\
\text { scutellata }\end{array}$ & 3 & 6 & Sep & III \\
\hline Euchaeta concinna $(\mathrm{E})$ & 4 & 4 & Feb & IV & Euterpina acutifronis & 5 & 14 & Jul & IV \\
\hline $\begin{array}{l}\text { Haloptilus longicornis } \\
\text { (M) }\end{array}$ & 4 & 2 & Jan & IV & Macrosetella gracilis \# & 10 & 45 & May & IV \\
\hline Labidocera minuta & 2 & 1 & Nov & IV & Metis jusseaumei & 2 & 4 & Mar & III \\
\hline Labidocera orsinii & 4 & 5 & Aug & IV & $\begin{array}{l}\text { Microsetella norvegica } \\
\#\end{array}$ & 12 & 157 & Nov & III \\
\hline Labidocera pavo \# & 11 & 106 & July & II & Microsetella rosea & 5 & 17 & Sep & III \\
\hline $\begin{array}{l}\text { Lucicutia flavicornis \# } \\
\text { (EB) }\end{array}$ & 8 & 57 & Sep & III & Monstrilla sp. & 1 & 1 & Jan & II \\
\hline Mecynocera clausi ( E) & 2 & 22 & Nov & IV & Nauplii & 12 & 1492 & Mar & II \\
\hline Paracalanus spp. \# & 10 & 103 & Jul & III & Copepodides & 12 & 6240 & Oct & II \\
\hline
\end{tabular}


Table 2. continued

\begin{tabular}{|c|c|c|c|c|c|c|c|c|c|}
\hline Species & $\mathbf{F r}$ & $\mathbf{C t}$ & Mo & St & Species & Fr & $\mathbf{C t}$ & Mo & St \\
\hline \multicolumn{5}{|l|}{ Planktonic crustaceans } & \multicolumn{5}{|l|}{ Planktonic medusae } \\
\hline Lucifer hanseni & 2 & 1 & Apr & III & Trachymedusae & 6 & 30 & Oct & IV \\
\hline Hyperiidae & 10 & 63 & Mar & IV & Leptomedusae & 6 & 5 & Sep & I \\
\hline Gammarus sp. & 4 & 7 & Nov & $\mathrm{I}$ & Limnomedusae & 1 & 4 & Jul & IV \\
\hline Mysis sp. & 4 & 2870 & Jun & IV & Nacromedusae & 2 & 1 & Apr & IV \\
\hline Cladocera & 8 & 1250 & Jul & III & Anthomedusae & 1 & 1 & Dec & I \\
\hline Ostracoda & 8 & 20 & May & II & Siphonophores & 11 & 65 & Oct & $\mathrm{I}$ \\
\hline \multicolumn{5}{|l|}{ Thaliacea } & \multicolumn{5}{|l|}{ Meroplankton } \\
\hline Doliolum denticulatum \# & 11 & 23 & Mar & $\mathrm{I}$ & Gastropod larvae & 12 & 3896 & Jun & II \\
\hline Thalia democratica & 6 & 5 & Jan & $\mathrm{I}$ & Lamellibranch larvae & 12 & 760 & Sep & IV \\
\hline \multicolumn{5}{|l|}{ Appendicularia } & Cirripid larvae & 12 & 60 & Oct & II \\
\hline Oikopleura spp. \# & 12 & 438 & Aug & II & Polychaete larvae & 12 & 499 & Oct & II \\
\hline \multicolumn{5}{|l|}{ Chaetognatha } & Brachyuran larvae & 12 & 314 & Jul & II \\
\hline Sagitta spp. \# & 12 & 197 & July & II & Other decapod larvae & 12 & 156 & Jul & II \\
\hline \multicolumn{5}{|l|}{ Planktonic molluses } & Ascidian larvae & 7 & 12 & Feb & 3 \\
\hline Atlanta spp. & 5 & 6 & Feb & $\mathrm{I}$ & Isopod larvae & 6 & 6 & Jul & IV \\
\hline Creseis clava\# & 8 & 134 & May & IV & Branchiostoma larvae & 3 & 3 & May & IV \\
\hline Creseis virgule\# & 8 & 6 & May & $\mathrm{I}$ & Echinoderm larvae & 4 & 4 & Feb & II \\
\hline Creseis sp.\# & 12 & 19 & Oct & $\mathrm{I}$ & Fish larvae & 12 & 11 & Jun & II \\
\hline Euclio sp. & 4 & 2 & Apr & III & Fish eggs & 12 & 416 & Jun & III \\
\hline \multicolumn{5}{|l|}{ Planktonic polychaetes } & & & & & \\
\hline Tomopteris sp. & 3 & 6 & Sep & III & & & & & \\
\hline Vanadis sp. & 2 & 1 & Apr & IV & & & & & \\
\hline
\end{tabular}

Copepods were the most diverse group, comprising 48 calanoid species, 13 cyclopoids and 7 harpacticoids. The other groups were represented by several crustaceans (Hyperiidae, Luciferidae, Gammaridae, Mysidacea, Cladocera, Ostracods), Thaliaceae, Larvaceae, Chaetognatha, planktonic molluscs (pteropods), planktonic polychaetes and cnidarian medusae. The average zooplankton count at sites II (7835 ind. $\left./ \mathrm{m}^{3}\right)$ was approximately twice that found the other three sites (3382 - $\left.3828 \mathrm{ind} . / \mathrm{m}^{3}\right)$. The monthly distribution displayed three concurrent peaks in March, July and November at sites I, III and IV and 2 peaks in May-June and October at site II (Fig. 4). Copepods constituted $70.5 \%$ of the total zooplankton count at both sites I and II, $65.7 \%$ at site III and $63.9 \%$ at site IV. Nauplii and copepodides dominated the copepod population by $15.4 \%$ and $56.1 \%$ respectively, while adult calanoids contributed by $13.1 \%$, cyclopoids (13.9\%) and harpacticoids (1.5\%). Only five species formed $63.8 \%$ of the total copepod count, comprising two calanoids (Acartia bispinosa: $14.5 \%$ and Clausocalanus furcatus: $12.1 \%$ ), and three cyclopoids (Oncaea scottodicarloi: 17.9\%, Oncaea mediterranea:11.2\%, and Farranula gibbula:8.1\%). As shown in Table 2, other copepod species displayed a flash appearance at some sites, like the cyclopoids Corycaeus spp. (4.9\%), O. nana (3.8\%), Oi. plumifera (2.2\%), the calanoids A. bispinosa $(83.1 \%)$, Acartia fossae (3.8\%), Paracalanus spp. (2.7\%), Clausocalanus arcuicornis (2.3\%), Acartia negligens (2\%), and the harpacticoid Microsetella norvegica (4.3\%). The 
dominant as well as temporal abundant copepod species showed different monthly distributional patterns at the sampling sites (Fig. 5A-D). Oncaea mediterranea dominated in late winter, early spring, and in mid-summer at all sites, with distinguished peaks in April and July at site II (Fig. 5A). Oncaea scottodicarloi showed the highest count during February - March at all sites, but with distinguished Peak at site II, and another peak in July at site II and in May at site IV (Fig. 5B). Clsauocalanus furcatus attained the highest count in March and July at all the sampling sites, in addition to a small peak in May at site IV (Fig. 5C). Farranula gibbulus displayed similar monthly patterns, with three small peaks in February-March and May, beside one distinguished peak in July (Fig. 5D). Furthermore, some copepods showed temporal considerably high count, like Corycaeus spp. that recorded three peaks in February-March, July and November, with different sizes at the sampling sites (Fig. 5E). Other copepod species showed high abundance at certain time only while occur in low count most of the year. For example, A. fossae attained pronouncedly high count in July only at all sites, $O$. nana (up to $822 \mathrm{ind} . / \mathrm{m}^{3}$ ) in June at site II only, and A. negligens (128 ind. $/ \mathrm{m}^{3}$ at site IV in May. Microsetella norvegica showed three peaks at all the sampling sites in August, November and February but with different sizes at each site. The other copepod species were found occasionally at one or more sites, but sometimes with high counts (Table 1).

Some of other holoplankton groups rather than copepods attained considerable high counts, such as Larvaceae, Chaetognatha, and some crustaceans (Cladocera and Mysidacae). The Larvaceans were represented mainly by Oikopleura spp., constituting $3.1 \%$ of the total zooplankton count, with a high peak in September at site II, and small peaks at the other sites (Fig. 6). The cladocerans comprised only Pseudevadne tergestina, that formed $2.1 \%$ of the total zooplankton and occurred from June to December, with a distinguished peak in July $\left(525-1250\right.$ ind. $\left./ \mathrm{m}^{3}\right)$ at all the sampling sites. Mysids were observed intermittently in low count during spring and summer, but they recorded a high count $\left(2870\right.$ ind. $\left./ \mathrm{m}^{3}\right)$ in June at site IV. The chaetognaths, Sagitta spp. were among the persistent zooplankters during the entire period of study, with a high peak (197 ind. $/ \mathrm{m}^{3}$ ) in July at site II, and small peak $\left(96\right.$ ind. $\left./ \mathrm{m}^{3}\right)$ in September at site III and two smaller peaks (59 and 71 ind. $/ \mathrm{m}^{3}$ ) in March at sites I and IV respectively. The adult planktonic molluscs (pteropods) were represented by five species, most of them occurred intermittently in low count $\left(<10 \mathrm{ind} . / \mathrm{m}^{3}\right)$, except Creseis clava which was more frequent and had a maximum of 51 ind. $/ \mathrm{m}^{3}$ in March and $134 \mathrm{ind} . / \mathrm{m}^{3}$ in May at site IV. Two thaliacean species only were recorded in the study area, Thalia democratica and Doliolum denticulatum. Thalia democratica was less frequent (mostly $<5$ ind. $/ \mathrm{m}^{3}$ ), while D. denticulatum existed in the whole area most of the year, except in summer, displaying a maximum of 23 ind. $/ \mathrm{m}^{3}$ in March at site I. The planktonic polychaetes comprised Tomopteris sp. and Vanadis sp. but both occurred occasionally. Different cnidarian medusae were observed, like Siphonophora, Trachymedusae, Leptomedusae, Limnomedusae, Nacromedusae and Anthomedusae, mostly in small number $\left(<5\right.$ ind. $\left./ \mathrm{m}^{3}\right)$. 
Siphonophora were the most widespread in the study area, attaining the highest counts $\left(30\right.$ - 64 ind. $\left./ \mathrm{m}^{3}\right)$ during September -October, while Trachymedusae occurred from October to February with the highest count $\left(28-29\right.$ ind. $\left./ \mathrm{m}^{3}\right)$ during October - November at sites IV. The planktonic larvae of the benthic animals displayed a pronounced role $(23.7 \%)$ in the zooplankton count, varying monthly between $6.1-39.0 \%$ at site I, $15-$ $36.4 \%$ at site II, $7.3-63.4 \%$ at site III and $9-51.7 \%$ at site IV. They demonstrated variable monthly count at the sampling sites (Fig. 7), with the clear dominance (76\%) of the mollusk gastropod veligers. The mollusk lamellibranch veligers and polychaete larvae displayed markedly lower contribution ( $10.8 \%$ and $7.4 \%$ respectively), while all other meroplanktonic larvae were found intermittently in low counts.

\section{Statistical analysis}

The two way ANOVA of sites and months on total abundance of zooplankton (Table 3) showed high significant differences $(\mathrm{P}=0.000)$, and Fisher least significance difference test (PLSD) indicated significant differences between site II and other sites (Table 4).

Table 3. Two-way ANOVA for monthly zooplankton count at the sampling sites.

\begin{tabular}{|l|l|l|l|l|l|}
\hline Source & DF & SS & MSI & F & P \\
\hline Site & 3 & 168344858 & 56114953 & 33.19 & 0.000 \\
\hline Month & 11 & 64335559 & 5848687 & 3.46 & 0.003 \\
\hline Error & 33 & 55786491 & 1690500 & & \\
\hline Total & 47 & 288466908 & & & \\
\hline
\end{tabular}

Table 4. Fisher Least significance Difference (PLSD) performed on the effect of site on the abundance of zooplankton.

\begin{tabular}{|l|l|l|l|}
\hline Site & I & II & III \\
\hline II & $*$ & & \\
\hline III & ns & $*$ & \\
\hline IV & $\mathrm{ns}$ & $*$ & $\mathrm{~ns}$ \\
\hline
\end{tabular}

The similarity dendrogram indicates high similarity between sites I, III and IV, as compared with site II (Fig. 8). The zooplankton diversity indices exhibited different patterns on both time and space scales, the Shanon index ( $\left.H^{\prime}\right)$ for the whole area varied between 1.6 and 2.3, with the lowest value from October to January and high values in late winter and early spring. Species richness (D) fluctuated from 2.53 in June and 5.34 in February, and evenness had values between 0.49 in October and 0.70 in July.

It is worth to mention that, 10 oceanic forms were sporadically observed in our shallow area, among them three species were considered as epipelagic (Euchaeta concinna, Mecynocera clause, and Scolecitrichopsis ctenopus), four mesopelagic (Haloptilus longicornis, Pleuromamma abdominalis, Macandrewella chelipes, and Lubbockia squillimana), one epi- to mesopelagic (Phaenna spinifera), one epi- to bathypelagic 
species (Lucicutia flavicornis), and one meso- to bathypelagic (Archescolecithrix auropecten).

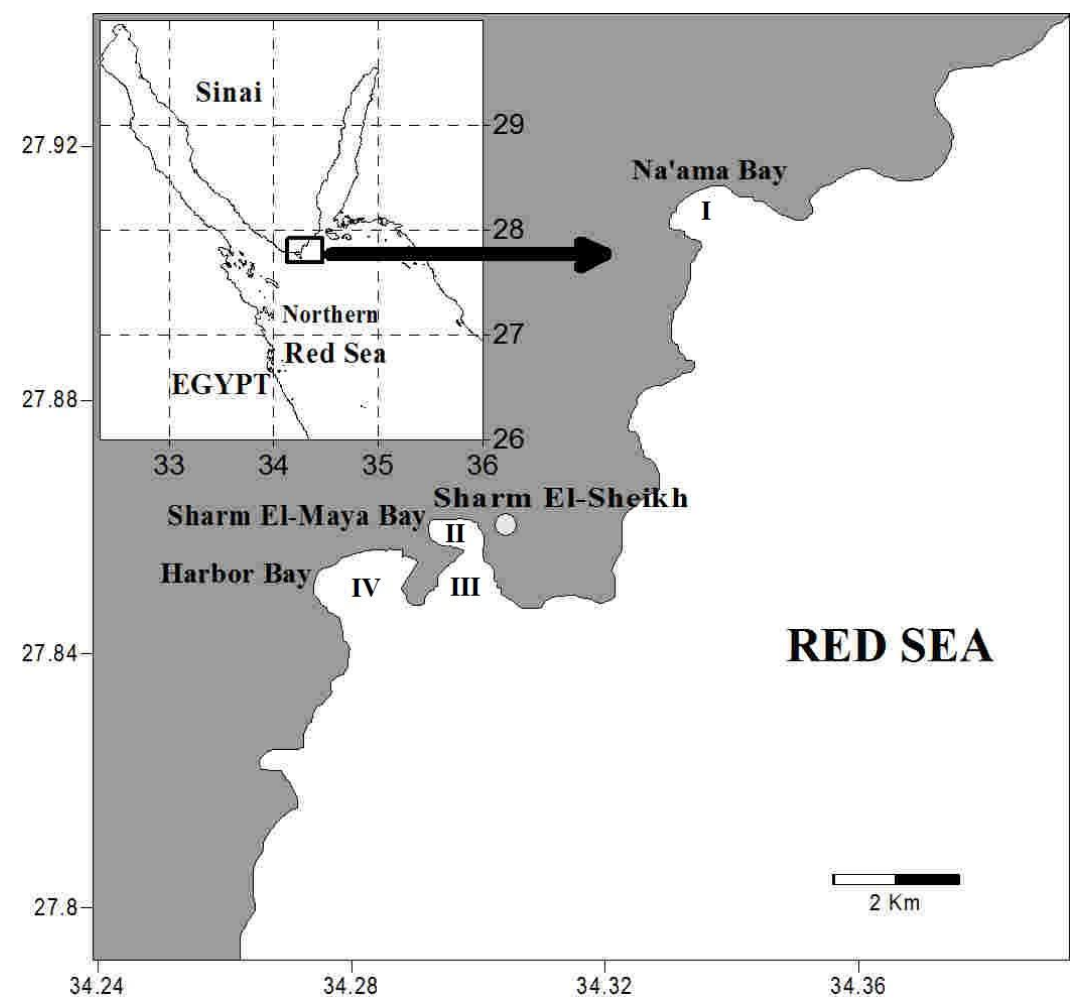

Fig. 1. The sampling sites at Sharm El-Sheikh, northern Red Sea.

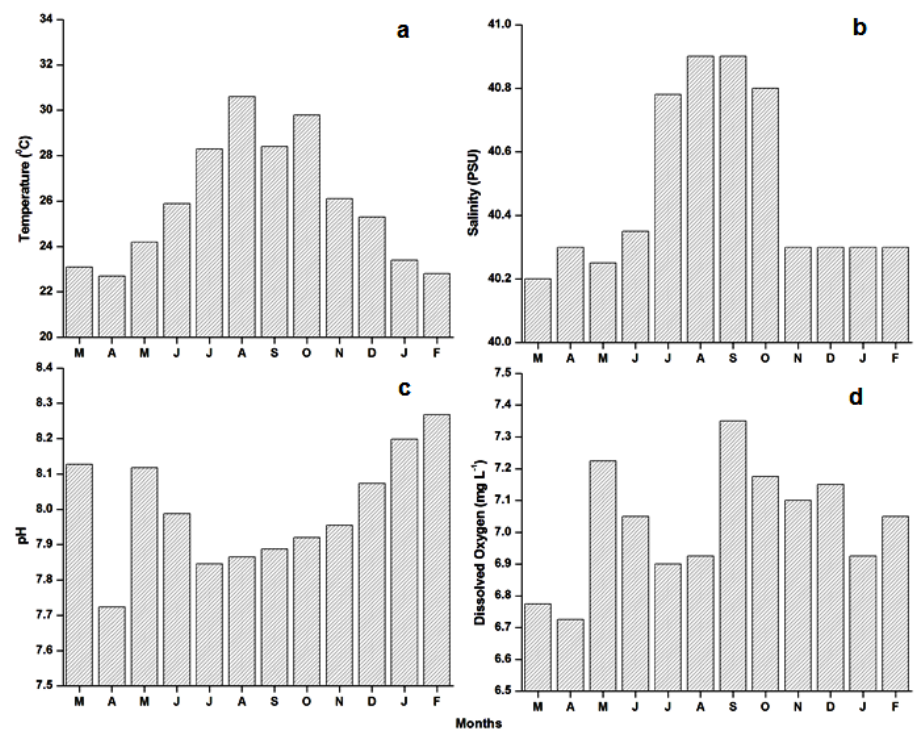

Fig. 2. The monthly average temperature (A), salinity (B), $\mathrm{pH}(\mathrm{C})$ and dissolved oxygen (D) for the whole study area. 


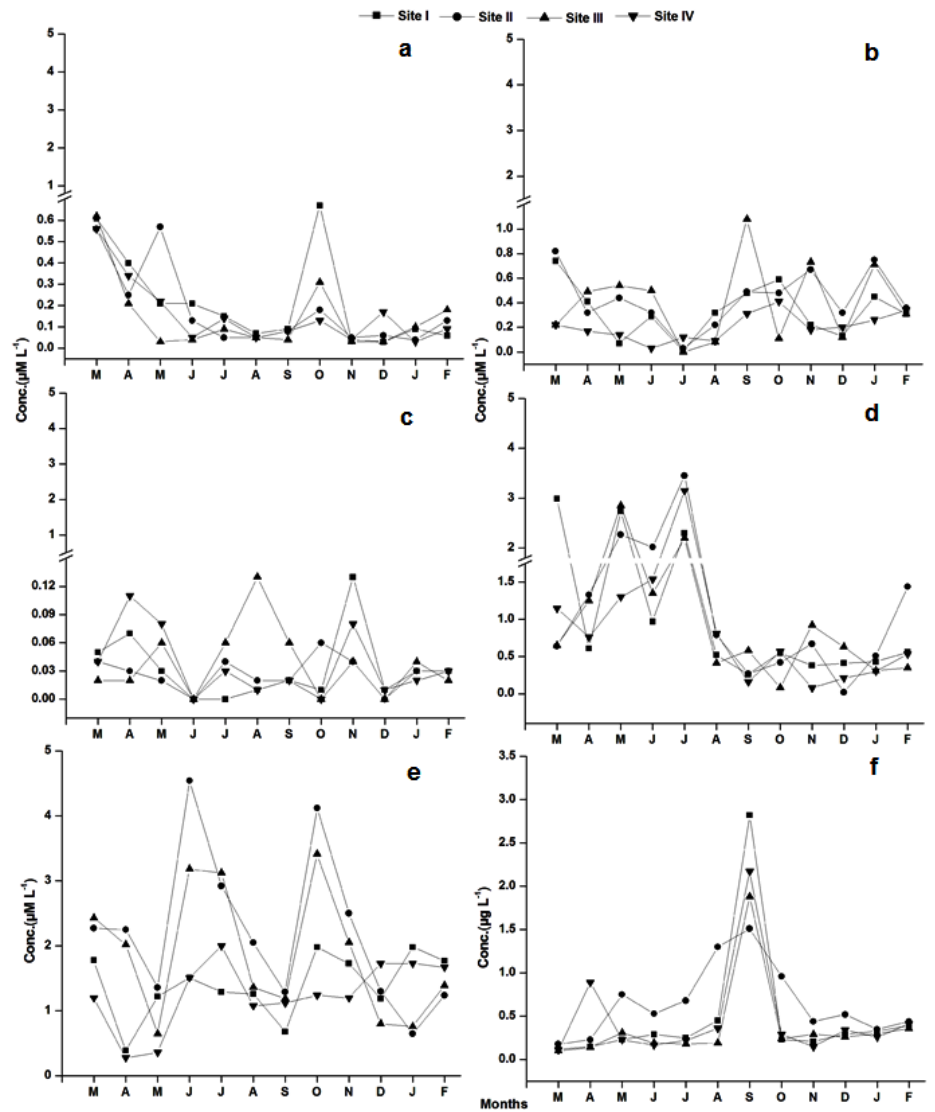

Fig. 3. The monthly average concentrations of phosphate (A), nitrate (B), nitrite (C), ammonia (D), silicate (E) and chlorophyll $a(\mathrm{~F})$ in the whole study area.

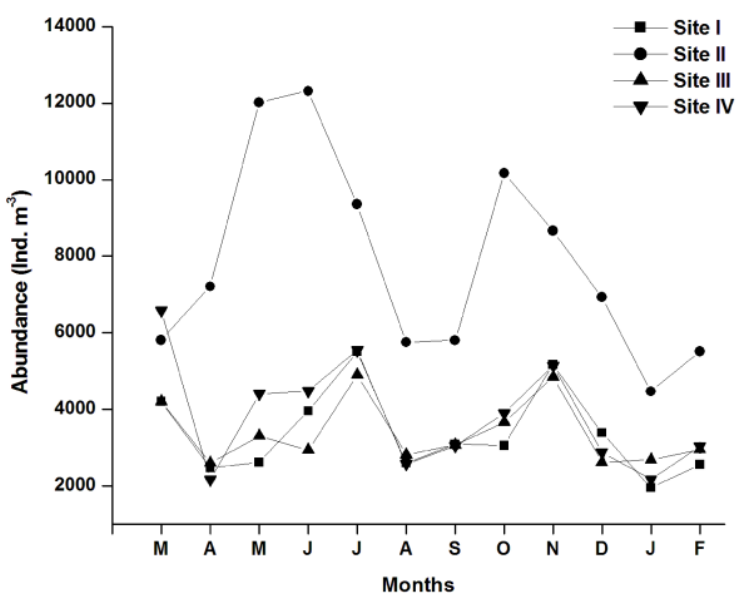

Figure 4. The monthly count of zooplankton at the sampling sites. 

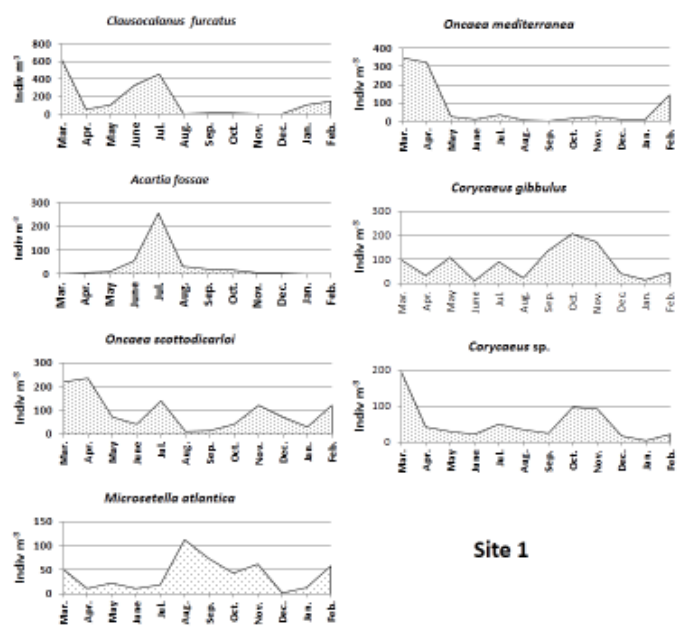

Site 1

Fig. 5A. The monthly count of dominant copepod species at site 1
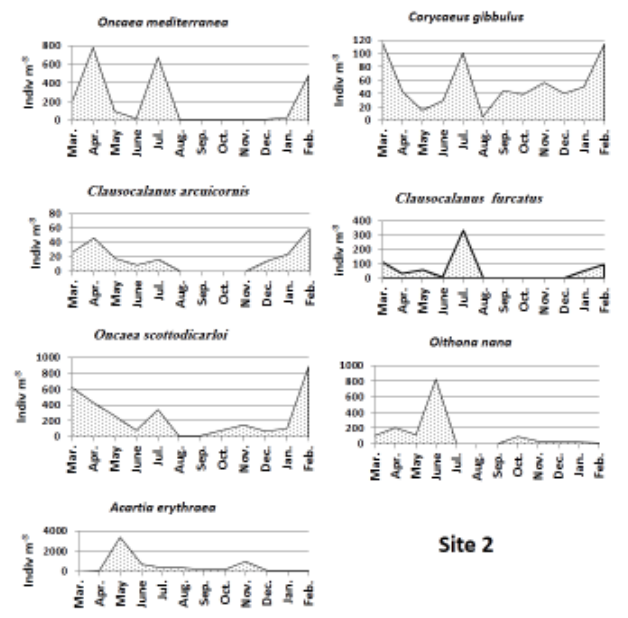

Site 2

Fig. 5B. The monthly count of dominant copepod species at site 2

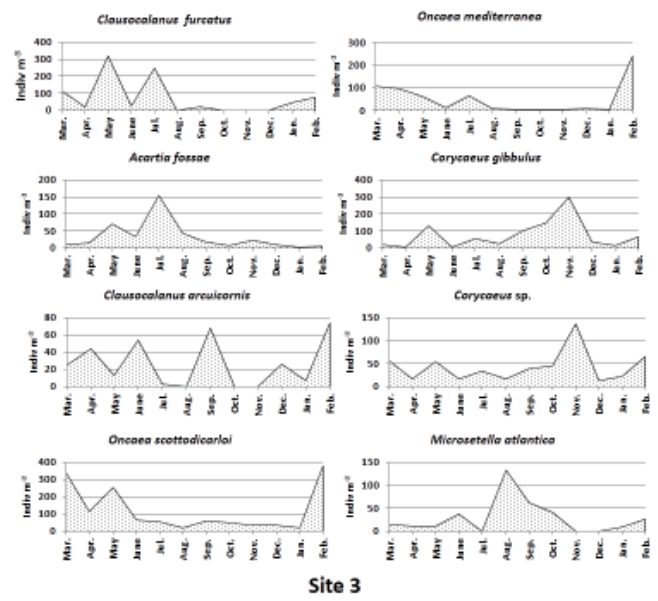

Fig. 5C. The monthly count of dominant copepod species at site 3 

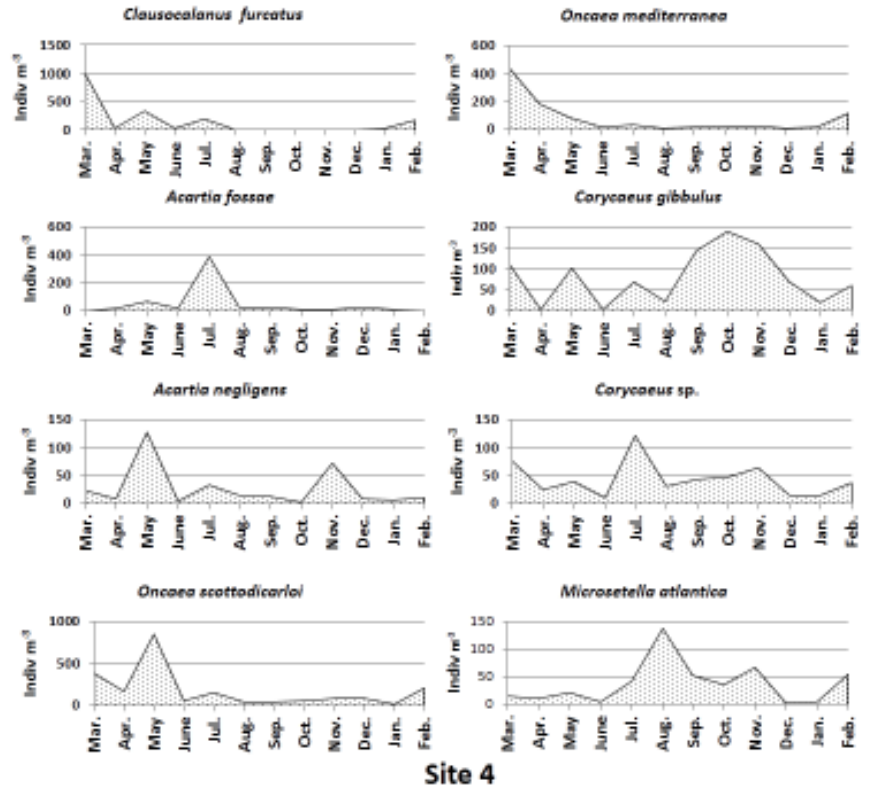

Fig. 5D. The monthly count of dominant copepod species at site 4

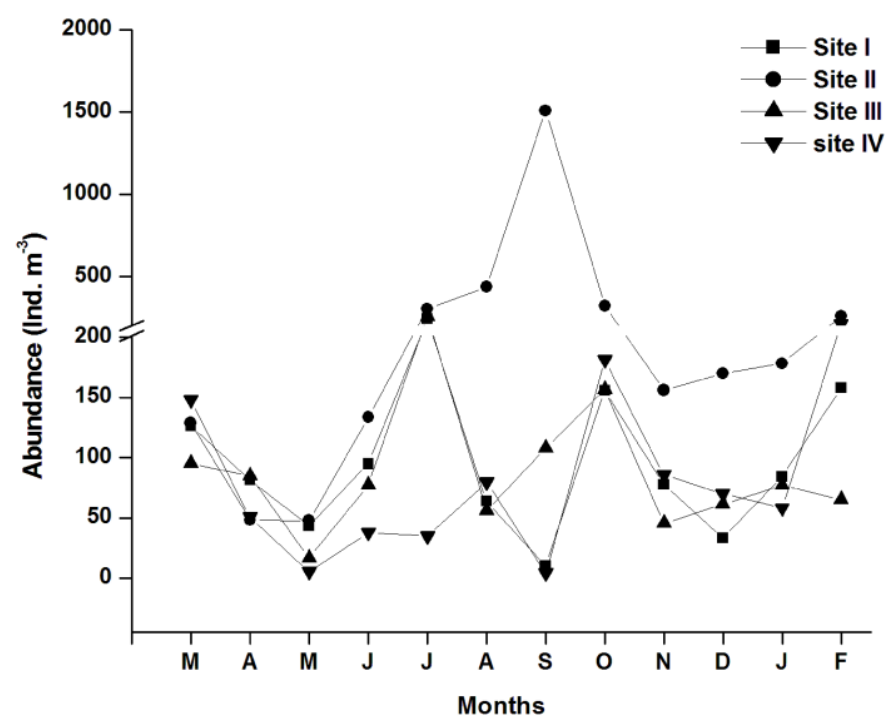

Figure 6. The monthly count of Oikopleura spp. at the sampling sites. 


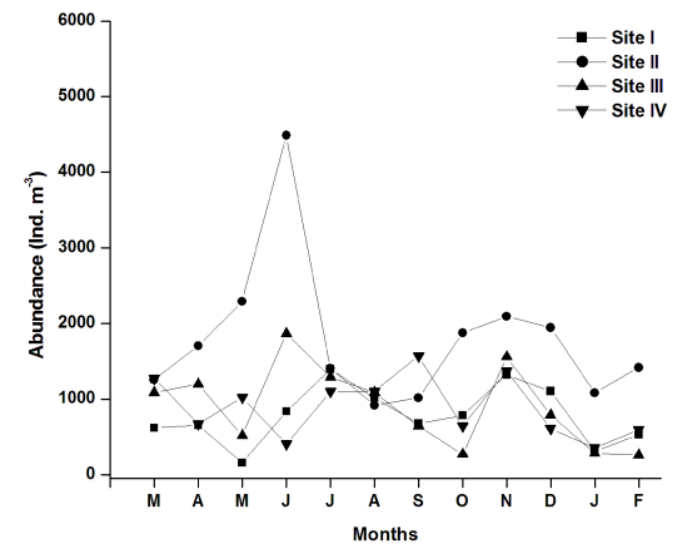

Figure 7. The monthly count of total meroplankton at the sampling sites.

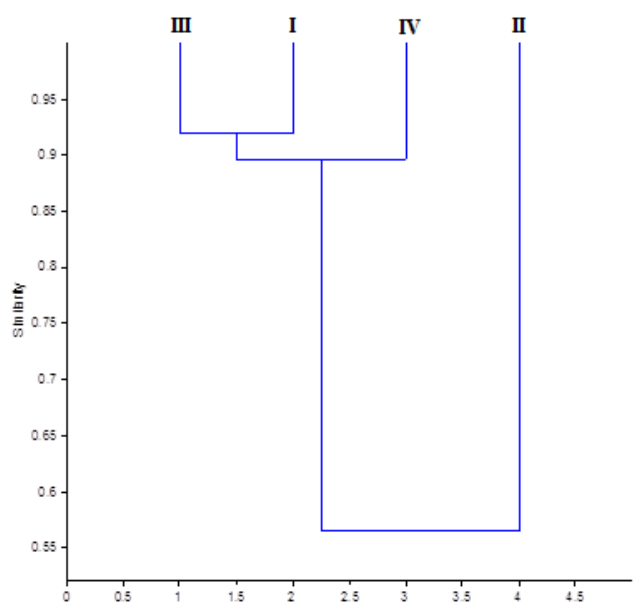

Figure 8. Bray-Curtis similarity dendrogram for zooplankton count among the sampling sites.

\section{DISCUSSION}

Despite the clear isolation of the sampling sites, the zooplankton community displayed pronounced similarity in both the species composition and the total count over most of Sharm El-Sheikh area, particularly among sites I, III and IV. Such similarity appeared to be associated with high similarity in the environmental conditions throughout the whole area, except at site II. This site slightly differ from others, being shallower and sheltered and contained ligher phytoplankton biomass, which explain the greater zooplankton count at this site. This agrees with previous findings that considred temperature, salinity and food availability are main factors affecting the dynamics of the zooplankton (e.g. Christou, 1998; Cornils, et al., 2005). However, copepods can use 
numerous autotrophic and heterotrophic organisms as food (Kleppel, 1993), change their feeding habits (Poulet, 1978), or have broad pattern of nutrition (Paffenhofer, 1984; Calbet et al., 2000; Cornils et al., 2007b), like Cl. furcatus and Ac. negligens, Paracalanus spp. and Oithona spp., which were among the abundant species, especially at site II.

The occurrence of $A$. bispinosa in pronouncedly high count at site II may be attributed to the fact that the Acartia adults inhabit sheltered and organically polluted areas (Kasahara et al., 1974). Similarly, the high abundance of $O$. nana at site II can be referred to its feeding habits, where it can feed on phytoplankton, copepod fecal pellets, microflagellates, dinoflagellates and ciliates (Lampitt, 1978; Turner, 2004). As compared to earlier studies, the present zooplankton counts in the southern part of the Gulf of Aqaba was higher than in the northern part of the gulf and the Red Sea proper (Table 5).

Table 5. The zooplankton abundance and copepod diversity in different part of the Red Sea

\begin{tabular}{|l|l|c|c|l|}
\hline Area & Date & $\begin{array}{l}\text { Range of total } \\
\text { zooplankton Count }\end{array}$ & $\begin{array}{l}\text { Copepod } \\
\text { species } \\
\text { No. }\end{array}$ & Reference \\
\hline $\begin{array}{l}\text { Egyptian side of Gulf of } \\
\text { Aqaba }\end{array}$ & 2008 & $251-7460$ & 81 & El-Serehy et al. (2013) \\
\hline $\begin{array}{l}\text { Coastal lagoons around } \\
\text { Jeddah }\end{array}$ & $\begin{array}{c}1990- \\
1991\end{array}$ & $340-4955$ & 43 & $\begin{array}{l}\text { Al-Aidaroos and Ghazali } \\
\text { (1998) }\end{array}$ \\
\hline $\begin{array}{l}\text { off Sharm El-Sheikh } \\
\text { (Southern Gulf of Aqaba) }\end{array}$ & $\begin{array}{c}2005- \\
2006\end{array}$ & $1510-2712$ & 68 & El-Sherbiny et al. (2007) \\
\hline $\begin{array}{l}\text { Sharm El-Mayia Bay } \\
\text { (Southern Gulf of Aqaba) }\end{array}$ & $\begin{array}{c}2000- \\
2001\end{array}$ & $1326-9825$ & 51 & Aamer et al. (2006) \\
\hline $\begin{array}{l}\text { off Sharm El-Sheikh } \\
\text { (Southern Gulf of Aqaba) }\end{array}$ & $\begin{array}{c}1995- \\
1996\end{array}$ & $1124-4952$ & 52 & Dorgham et al. (2012) \\
\hline $\begin{array}{l}\text { Egyptian side of Gulf of } \\
\text { Aqaba }\end{array}$ & $\begin{array}{c}1994- \\
1995\end{array}$ & $1906-4138$ & 27 & $\begin{array}{l}\text { Khalil and Abd El-Rahman } \\
(1997)\end{array}$ \\
\hline $\begin{array}{l}\text { Saudi coast of the southern } \\
\text { Red Sea }\end{array}$ & $\begin{array}{c}\text { Mar.-Apr. } \\
2011\end{array}$ & $1058-25787$ & 100 & Al-Aidaroos et al. (2016) \\
\hline Northern Gulf of Aqaba & $\begin{array}{c}2002- \\
2003\end{array}$ & $245-3065$ & - & Cornils et al. (2007b) \\
\hline Northern Gulf of Aqaba & $\begin{array}{c}1986- \\
1989\end{array}$ & $33-317$ & 30 & $\begin{array}{l}\text { Echelman and Fishelson } \\
\text { (1990) }\end{array}$ \\
\hline Central Red Sea & $\begin{array}{c}\text { Nov. } \\
1977\end{array}$ & 200 & - & Weikert (1982) \\
\hline $\begin{array}{l}\text { Saudi Arabian coastal waters } \\
\text { of the Red Sea }\end{array}$ & Sep. 2012 & $787-50642$ & 86 & Kürten et al. (2015) \\
\hline $\begin{array}{l}\text { Southern Gulf of Aqaba } \\
\text { (Sharm El-Sheikh) }\end{array}$ & $\begin{array}{l}1995- \\
1996\end{array}$ & $2169-12319$ & 71 & Present study \\
\hline
\end{tabular}

Scuh differences could be due to different mesh size of the plankton net (Al-Najjar, 2005), or to environmental differences, particularly the food availability (Aamer et al., 2006; El-Sherbiny et al., 2007; Dorgham et al., 2012). The lower phytoplankton biomass at the northern part than the southern part of Aqaba Gulf (Abdel Halim et al., 
2007) could be a reason of regional differences in zooplankton count along the gulf, as significant relationship was reported between the abundance of both plankton components in the Gulf of Aqaba (Echelman \& Fishelson, 1990). The present study recorded higher zooplankton count than that found previously in the open water (Aamer et al., 2006; El-Sherbiny et al., 2007; Dorgham et al., 2012), due rich zooplankton in near-reef areas (Echelman \& Fishelson, 1990). Although zooplankton peaks in the shallow waters coincided with those occurred in the open water (Aamer $\boldsymbol{e t}$ al., 2006; ElSherbiny et al., 2007), the peaks in our area showed different patterns at the sampling sites, indicating that both the timing and extent of zooplankton maximum experienced wide variation along the Gulf of Aqaba. This was supported by previous observations on peaks in summer (Al-Najjar, 2000; Farstey et al., 2002, El-Sherbiny et al., 2007; Dorgham et al., 2012), in winter (Echelman and Fishelson, 1990; Khalil and AbdelRahman, 1997), in spring (Almeida Prado-Por, 1983; Al-Najjar, 2000), or in the four seasons (Aamer et al., 2006). Copepods by count are the dominant zooplankton component (>70\%) everywhere in the marine habitat (e.g. Madhupratap and Haridas, 1990; Mazzocchi and Ribera d'Alcala, 1995). However, this contribution experienced greatly variation during the entire period of study (33.3-90.8\%) as compared to other parts of the Gulf of Aqaba, like 79 -95\% (Al-Najjar, 2000; Cornils, 2005) and 58-92\% (Cornils et al., 2007a) 78.6-93.2\% (Dorgham et al., 2012), 64.5-66\% (Aamer et al., 2006), 69.6-91.1\% (El-Sherbiny et al., 2007) and 75.5\% (Khalil and Abdel-Rahman, 1997). The environmental conditions, food availability, trophic relationship between copepods and other biota (both prey and predators) and/or using of different mish sizes may explain the spatial differences in copepod contribution.

Copepodides outnumbered nauplii by more than three 3 folds over the area of study, and also in the open water of Sharm El-Sheikh (El-Sherbiny et al., 2007; Dorgham et al., 2012). By contrary, nauplii were the dominant in other parts of the Red Sea (AbdelRahman, 1993), the ROPME Sea area (Michel et al., 1986a, b; Dorgham and Hussein, 1997) and along the Egyptian Mediterranean Coast (Abdel-Aziz, 2000; 2001). Beside the differences in ecological conditions, the spawning seasons, life cycle, and number of broods of the dominant copepod species play main role in the abundance of both copepod larval stages (Dowidar and El-Maghraby, 1970; Abdel-Aziz, 2001).

Despite of low diversity of cyclopoids (13 species) their numerical abundance exceeded that of the high diverse calanoids (48 species) at most of the sampling sites. This pattern was also observed in the ROPME Sea area (Michel $\boldsymbol{e t}$ al., 1986a, b; Dorgham and Hussein, 1997) and in the Egyptian Mediterranean coast (Abdel-Aziz, 1997). However, calanoids outnumbered cyclopoids in the northern Gulf of Aqaba (Cornils et al., 2007a) and in the Suez Bay (Abdel-Rahamn, 1993). On the other hand, our study recorded the highest count of calanoids in late spring and early summer, cyclopoids in late winter and early spring and harpacticoids in summer. Dorgham et al. (2012) recorded maximum count for harpacticoids in summer, fpr calanoid in winter and for cyclopoids in autumn, 
while El-Sherbiny et al. (2007) observed the highest calanoid in summer and cyclopoids in spring and autumn. The thermal affinity of the dominant species of each copepod group may play a role in controlling their spawning and growth pattern. Other than copepods, the holoplanktonic groups had low count, but some of them displayed temporal high counts. The appendicularians peak in our samples occurred during September while pronounced low peaks were recorded in the Gulf of Aqaba, in summer (Echelman and Fishelson, 1990; El-Sherbiny et al., 2007), summer and winter (Dorgham et al., 2012) late spring and early summer (Fenaux, 1979; Cornils et al., 2007a). The cladoceran $P$. tergestina attained its peak in the southern Gulf of Aqaba either in July (Present study, El-Sherbiny et al., 2007) or in June (Aamer et al., 2006), but with pronouncedly different values. This coincides with other observations that confirmed the occurrence of cladocerans among the summer zooplankton taxa (Komarovsky, 1958; Calbet et al., 2001; Cornils, 2005). During the present study, the chaetognaths recorded their peak in March, July and September, but Cornils et al. (2005) observed these paeks in April/June and October/November. In the meantime, the chaetognaths count in our area was clearly higher than those recorded in different parts of the Gulf of Aqaba (Kimor and Golandsky, 1977, El-Sherbiny et al., 2007; Khalil and Abdel-Rahman, 1997; Cornils et al., 2005; 2007a; Dorgham et al., 2012), but was lower than in the open water off Sharm El-Sheikh (Aamer et al., 2006). It seems that the abundance of chaetognaths was related to that of copepods, as indicated from the significant correlation between the two groups (Table 6) and also from the relationship between Sagitta spp. and Oncaea spp. in the area of Regional Organization for Protection of the Marine Environment (ROPME) of the Gulf Region (Michel et al., 1986a, b), since Oncaea spp represent preferable food for chaetognaths (Sullivan, 1980; Kimmerer, 1984).

Table 6. Significant correlation between Sagitta spp. and some copepod species at the sampling sites.

\begin{tabular}{|l|l|l|l|l|}
\hline Copepod species & St I & St II & St III & St IV \\
\hline Acartia fossae & & 0.884 & & \\
\hline Acrocalanus gibber & 0.7303 & & 0.696 & 0.9057 \\
\hline Nannocalanus minor & & & 0.765 & \\
\hline Undinula vulgaris & & & 0.769 & \\
\hline Calocalanus pavo & & 0.77 & & \\
\hline Candacia truncata & & & 0.765 & \\
\hline Clausocalanus furcatus & & 0.85 & & 0.7646 \\
\hline Corycaeus spp. & 0.6983 & 0.69 & & \\
\hline Labidocera pavo (adults) & & 0.823 & & \\
\hline Labidocera pavo (copepodides) & & 0.945 & & \\
\hline Lucicutia flavicornis & & & 0.783 & \\
\hline Macrosetella gracilis & & & 0.604 & \\
\hline Oncaea mediterranea & & & & 0.6003 \\
\hline Oncaea scottodicarloi & & & & 0.5859 \\
\hline
\end{tabular}


The pteropod mollusk (Cresies acicula) sustained the highest count in May during the present study and also in the offshore waters (El-Sherbiny et al., 2007), indicating spring as the preferable season for its reproduction. The abnormal abundance of Mysis species in June at site IV was accompanied by pronouncedly low zooplankton count, may be due to intensive preying of Mysis on the zooplankton. Mysis species were found to be herbivorous and predaceous feeder (Larkin, 1948), detritivore (Tattersall and Tattersall, 1951) and opportunistic omnivore (Grossnickle, 1982).

The contribution of meroplankton (6.1-63.4\%) during the present study was conspicuously greater than that (9\%) off Sharm El-Sheikh (El-Sherbiny et al., 2007), 17.9\% in the whole Gulf (Khalil and Abdel-Rahman, 1997), 3-30\% in the northern Gulf (Cornils, 2005), but it was close to the records of Aamer et al. (2006). The difference in meroplankton count reflects the numerical density of the benthic animals and their production efficiency at the different regions. The conspicuous prevalence of gastropod veligers in our area and in whole Gulf of Aqaba (Abdel-Rahman, 1993, Khalil and Abdel-Rahman, 1997; Cornils, 2005; Aamer et al., 2006; El-Sherbiny et al., 2007; Dorgham et al., 2012) confirms the occurrence of dense population of benthic molluscs. However, the high meroplankton production in the area of study may be attributed to the rich coral reefs and highly diversified coastal communities (e.g. Loya, 1972; Schuhmacher, 1977), where coastal currents, semidiurnal tides and winds play a role in the distribution of meroplankton (Belgrano and Dewarumez, 1995).

It is worth to mention that, the mesopelagic or epipelagic species found in the coastal areas of Sharm El Sheikh during the present study reflected the effect of vertical water mixing, particularly in winter. These species were found previously in the oceanic water off Sharm El Sheikh (El-Sherbiny et al., 2007; Dorgham et al., 2012). In addition, seasonal vertical migrator species were found in the study area, like Rincalanus nasutus and M. tenuicornis. Rincalanus nasutus was observed in February when it undergoes seasonal vertical migration and late copepodite stages and females feed and reproduce at the surface (Schnack-Schiel et al., 2008). Mesocalanus tenuicornis was found in bathypelagic area, but it was considered a rather seasonal vertical migrator than a bathypelagic species (Amber and Miller 1987; Williams and Conway, 1988; Bradford-Grieve and Ahyong, 2010). Also, the mesopelagic $P$. abdominalis has never been recorded from the Red Sea and the Gulf of Aqaba. Farstey et al. (2002) stated that the whole genus Pleuromamma does achieve diel vertical migration, while Pleuromamma indica was considered to be the only Pleuromamma species in the Gulf of Aqaba and the northern Red Sea (Almeida Prado-Por, 1983; Beckmann, 1984). Thus, P. abdominalis could be considered a new record to the concerned area.

Our records for other oceanic forms coincided with previous observations, whereas Lubbockia squillimana is mesopelagic, Lucicutia flavicornis: epi- to bathypelagic, but predominantly epipelagic, Archescolecthrix auropecten: meso- to bathypelagic, 
Macandrewella chelipes: probably mesopelagic as most other species of the genus, and Scolecitrichopsis ctenopus: epipelagic (Razouls et al., 2015)

The little spatial change in the number of species, particularly copepods (54-63 species), might be explained by the slight differences in environmental conditions, while the wide monthly variations (12-42 species) at each of the sampling sites could be associated with the seasonal changes in the water temperature. However, the statistical analysis exhibited in most cases significant negative correlation between the number of calanoid and cyclopoid species and temperature $(r=-0.425 \&-0.433, n=48, \mathrm{p}<0.05)$, salinity $(r=-0$. $281 \&-0.353, \mathrm{n}=48, \mathrm{p}<0.05)$, silicate $(\mathrm{r}=-0.417 \&-0.435, \mathrm{n}=48, \mathrm{p}<0.05)$, and $\mathrm{pH}(\mathrm{r}=$ $0.3587 \&-0.3195, \mathrm{n}=48, \mathrm{p}<0.05)$.

The diversity is usually used to indicate the healthy condition of ecosystem (Magurran, 1988), as its temporal variation may reflect the succession of community structure and could be used as an index for assessing the environmental stress (Omori and Ikeda, 1984). The Shannon index ( $\left.\mathrm{H}^{\prime}\right)$ fluctuated between 1.6 and 2.3 during the investigation period and remained lower than that (2.603-3.238 in the northern Gulf of Aqaba (Cornils, 2005). The spatial differences in diversity between the sampling sites was associated with the evenness and the number of species, whereas high significant correlation was observed between the number of species and both evenness $(r=-0.6, p$ $<0.05)$ and species richness $(\mathrm{r}=0.874, \mathrm{p}<0.05)$, and significant correlation of diversity index with evenness $(r=0.911, p<0.05)$. On the other hand, winter community in the whole area of study, sustained the highest number of species diversity (66 species), particularly in December and January, which coincided with the highest species richness, the lowest evenness, and the lowest diversity index. The seasonal differences in the number of zooplankton species seems to be common in the Red Sea (Sewell, 1948; Halim, 1969; Weikert, 1980, a,b, 1987; Beckmann, 1984), but winter was characterized by the highest number of species (Halim, 1969). Most copepod species in the Gulf of Aqaba are either circumglobal or common in the Indian Ocean, and they are transported by the constant inflow of surface water from the Red Sea (Cornils, 2005). On the other hand, the large number of persistent species reflects the stability of the zooplankton community in the study area, as a result of the slight differences in the environmental conditions between the sampling sites.

\section{CONCLUSION}

The mesozooplankton community in the shallow water of Sharm El-Sheikh area was high diversity (91 species) and relatively high abundant (annual average: $3382-7835$ ind. $/ \mathrm{m}^{3}$ ) at the sampled sites. Copepods were the major component (48 species), constituting $63.9 \%-70.5 \%$ of the total zooplankton count throughout the area, with the dominance of a few species. The occurrence of 10 oceanic forms of epipelagic, mesopelagic, and epi- to bathypelagic origin indicated the effect of winter mixing of deep water on zooplankton community of Sharm El Sheikh shallow water. 


\section{REFERENCES}

Aamer, M. A.; El-Sherbiny, M. M.; Gab-Alla, A. A. and Kotb, M. M. (2006). Ecological studies on zooplankton standing crop of Sharm El-Maiya Bay, Sharm El Sheikh, northern Red Sea, CATRINA 1 (1): 73-80.

Abdel-Halim, A. M.; Aboel-Khair, E. M.; Fahmy, M. A. and Shridah, M. A. (2007). Environmental assessment on the Aqaba Gulf coastal waters, Egypt. Egyptian Journal of Aquatic Research 33(1): 1-14.

Abdel-Aziz, N. E. (2000). Zooplankton dynamics and ecology of an eutrophic area, Egypt. Arab Gulf Journal for Scientific Research 18(2): 110-121.

Abdel-Aziz, N. E. (2001). Zooplankton community under the stress of polluted land based effluents in Abu Qir Bay, Alexandria, Egypt. Bulletin Faculty of Science, Alexandria University 41(1,2): 57-73.

Abdel-Aziz, N. E. (1997). Zooplankton production along Egyptian Mediterranean Coast at Alexandria, with special reference to life history of one copepod species. Ph.D. Thesis., Faculty of Science, Mansoura Univ.

Abdel-Rahman, N. S. (1993). Ecological studies on the distribution of zooplankton communities in the northern part of the Suez Gulf Suez Bay. M. Sc. Thesis, Faculty of Science, Suez Canal Univ. 316pp.

Abdel-Rahman, N. S. (1999). Check-list of crustacean copepods in the Gulf of Aqaba. Egyptian Journal of Aquatic Biology and Fisheries 3: 35-54.

Abu El-Regal. M. A.; El-Wazeer, A.; Abou Elnaga, Z. Sh. and Amr, A. A. (2018). Composition and Spatio-Temporal Distribution of Zooplankton Community in the Egyptian Red Sea Coast at Hurghada. Egyptian Journal of Aquatic Biology \& Fisheries 22(3): 1- 12.

Al-Aidaroos, A. M. and Ghazali, F.M. (1998). Zooplankton of Highly Eutrophic, Sewage Polluted Coastal Lagoons Off Jeddah, Central Red Sea. Journal of King Abdul Aziz University Marine Science 9: 131-148.

Al-Aidaroos, A. M.; El-Sherbiny, M. and Gopikrishna, M. (2016). Spatial heterogeneity of zooplankton abundance and diversity in the Saudi coastal waters of the Southern Red Sea. Indian journal of Geo-Marine Sciences 45(1): 70 -85.

Almeida Prado-Por, M. (1983). The diversity and dynamics of Calanoida (Copepoda) in The northern Gulf of Elat (Aqaba), Red Sea. Oceanologica Acta 6:139-145.

Al-Najjar, T. H. (2000). The seasonal dynamics and grazing control of phyto- and 
mesozooplankton in the northern Gulf of Aqaba. Ph.D. Thesis, University of Bremen, Bremen, Germany.

Al-Najjar, T. H. (2005). Seasonal and spatial variations in mesozooplankton biomass In the most northern part of the Gulf of Aqaba during 2003. Zoology in the Middle East Journal 34: 87-92.

Al-Najjar, T.; Badran, M. and Zibdeh, M. (2002). Seasonal cycle of surface zooplankton biomass in relation to the chlorophyll a in the Gulf of Aqaba, Red Sea. Abhath Al-Yarmouk Basic Science and Engineering 12 (1): 109-118.

Ambler, J. W. and Miller, C. B. (1987). Vertical habitat-partitioning by copepodites and adults of subtropical oceanic copepods. Mar. Biol., 94, 561-577.

APHA (1985). Standard Method for the Examination of Water and Wastewater. 16th Edition, American Public Health Association, Washington DC.

Beckmann, W. (1984). Mesozooplankton Distribution on a Transect from the Gulf of Aden to the Central Red Sea During the Winter Monsoon". Oceanologica Acta 7: 87-102.

Belgrano, A. and Dewarumez, J.M. (1995). The influence of tidal-induced variability on the distribution of meroplankton larvae in the southern bight of the North Sea. Oceanologia Acta 18(5):523-530.

Böttger-Schnack, R.; Hagen, W. and Schnack-Schiel, S. B. (2001). The microcopepod fauna in the Gulf of Aqaba, northern Red Sea: species diversity and distribution of Oncaeidae (Poecilostomatoida). Journal of Plankton Research, 23(9): 1029-1035.

Bradford-Grieve J. M. and Ahyong, S. T. (2010) Phylogenetic relationships among genera in the Calanidae (Crustacea: Copepoda) based on morphology. Journal of Natural History 44: 279-299.

Calbet, A.; Landry, M. R. and Nunnery, S. (2001). Bacteria-flagellate interactions in The microbial food web of the oligotrophic subtropical North Pacific. Aquatic Microbial Ecology 23: 283-292.

Calbet, A.; Landry, M. R. and Scheinberg, R. D. (2000). Copepod grazing in a subtropical bay: species-specific responses to a midsummer increase in nanoplankton standing stock. Marine Ecological Progress Series 193: 75-84.

Casas L., Pearman, J. K. and Irigoien, X. (2017). Metabarcoding reveals seasonal and temperature-dependent succession of zooplankton communities in the Red Sea. Frontiers in Marine Science 4:241. doi: 10.3389/fmars.2017.00241

Christou, E. D. (1998). Interannual variability of copepods in a Mediterranean Coastal Area (Saronikkos Gulf, Aegean Sea). Journal of Marine Systems 15: 523-532. 
Conway, D. V. P.; White, R. G.; Hugues-Dit-Ciles, J.; Gallienne, C. P. and Robins, D. B. (2003). Guide to the coastal and surface zooplankton of the south western Ind.ian Ocean, Occas. Publ. No. 15, Marine Biological Association of United Kingdom 354 pp.

Cornils, A. (2005). Seasonal Dynamics of the Copepod Population in an Oligotrophic Environment- the northern Gulf of Aqaba (Red Sea). Ph D Thesis, Bremen, Germany.

Cornils, A.; Schnack-Schiel, S. B., Al-Najjar, T.; Badran, M. I., Rasheed, M.; Manasreh, R. and Richter, C. (2007a). The seasonal cycle of the epipelagic mesozooplankton in the northern Gulf of Aqaba (Red Sea). Journal of Marine Systems 68: 278-292.

Cornils, A.; Schnack-Schiel, S. B.; Böer, M.; Graeve, M.; Struck, U.; Al-Najjar, T. and Richter, C. (2007b). Feeding of Clausocalanids (Calanoida, Copepoda) on naturally Occurring particles in the northern Gulf of Aqaba (Red Sea). Marine Biology 151: $1261-1274$.

Delalo, E. P. (1966). Distribution of the zooplankton biomass in the Red Sea and the Gulf of Aden, winter 1961/62. Okeanol. issled 15: 131-139.

Dorgham, M. M. and Hussein M. M. (1997). Zooplankton dynamics in a neritic area of The Arabian Gulf (Doha Harbour) Arab Gulf Journal for Scientific Research 15 (2): $415-435$.

Dorgham, M. M.; El-Sherbiny, M. M. and Hanafi, M. H. (2012). Vertical distribution of zooplankton in the epipelagic zone off Sharm El-Sheikh, Red Sea, Egypt. Oceanologia, 54 (3): 473-489.

Dowidar, N. M. and El-Maghraby, A. M. (1970). The neritic zooplankton of the South Eastern Mediterranean at Alexandria, I- Distribution and ecology of the zooplankton organisms with special reference to copepods. Bulletin of Institute of Oceanography and Fisheries. 1: 225- 273.

Echelman, T. and Fishelson, L. (1990). Surface zooplankton dynamics and community structure in the northern Gulf of Aqaba, Red Sea. Marine Biology 107(1): 179 - 190.

El-Serehy, H. A.; Abdel-Rahman, N. S.; Al-Rasheid, K. A; Al-Misned, F. A.; Shafik, H. M. and Bahgat, M. M. (2013). Copepod dynamics in the epipelagic zone of two different regional aquatic ecological basins at the northern Red Sea, Egypt. Life Science Journal, 10(4): 405 - 412. 
El-Sherbiny, M. M.; Hanafy, M. H. and Aamer, M. A. (2007). Monthly Variations in abundance and Species Composition of the Epipelagic Zooplankton off Sharm El Sheikh, Northern Red Sea. Research Journal of Environmental Sciences, 1: 200210.

Farstey, V.; Lazar, B. and Genin, A. (2002). Expansion and homogeneity of the vertical distribution of zooplankton in a very deep mixed layer. Marine Ecology Progress Series 238: 91-100.

Fenaux, R. (1979). First data on the ecology of Appendicularia in the Gulf of Eilat. Isr. Jour. Zool. 28: 177-192.

Giesbrecht, W. (1892). Systematik und Faunistik der pelagischen Copepoden des Golfes von Neapel und der angrenzenden Meeres-Abschnitte, [in:] Fauna und Flora des Golfes von Neapel, 19:1-831.

Gordeyeva, K. T. (1970). Quantitative distribution of zooplankton in the Red Sea. Okeanologija, Mosk. 10: 867-871

Grossnickle, N. E. (1982). Feeding habits of Mysis relicta - an overview. Hydrobiologia 93: 101- 107.

Halim, Y. (1969). Plankton of the Red Sea and the Arabian Gulf. Deep Sea Research 31(6-8):969-982.

Hanafy, M. H.; Dorgham, M. M. and El-Sherbiny, M. M. (1998). Zooplankton community in mangal ecosystem on Sharm El-Sheikh coast, Red Sea. Egyptian Journal for Aquatic Biology and Fisheries 2 (4): 465-482.

Heron, G. A. and Bradford-Grieve, J. M. (1995). The marine fauna of New Zealand: Pelagic Copepoda: Poecilostomatoida: Oncaeidae. New Zealand Oceanographic Institute Memoir 104pp.

Kasahara, S.; Uye, S. and Onbé, T. (1974). Calanoid copepod eggs in sea bottom muds. Marine Biology 26: 167-171.

Khalil, M. T. and Abdel-Rahman, N. S. (1997) Abundance and diversity of surface zooplankton in the Gulf of Aqaba, Red Sea, Egypt. Journal of Plankton Research 19 (7): 927-936.

Kimmerer, W. J. (1984). Spatial and temporal variability in egg production rates of the calanoid copepod Acrocalanus inermis. Marine Biology 78:165-169.

Kimor, B. and Golandsky, B. (1977). The microplankton of the Gulf of Eilat: aspects of seasonal and bathymetric distribution. Marine Biology 42 (1): 55-76. 
Kleppel, G. S. (1993). On the diets of calanoid copepods. Marine Ecology Progress Series 99: 183- 195.

Komarovsky, B. (1958). The occurrence of Evadne tergestina Claus in the summer plankton of the Gulf of Elat (Aqaba). Red Sea. Fisheries Research Station Bulletin $16: 1-2$.

Kürten, B.; Khomayis, H.S.; Devassy, R.; Audritz. S.; Sommer, U., Struck, U.; El Sherbiny, M. M. and Al-Aidaroos, A.M. (2015). Ecohydrographic constraints on biodiversity and distribution of phytoplankton and zooplankton in coral reefs of the Red Sea, Saudi Arabia. Marine Ecology 36:1195-1214.

Lampitt, R. S. (1978): Carnivorous feeding by a small marine copepod. Limnol. Oceanogr. 23, 1228-1231.

Larkin, P. A. (1948). Pontoporeia and Mysis in Athabaska, Great Bear, and Great Slave Lakes.Bulletin of Fish Research Board of Canada 78: 1-33.

Loya, Y. (1972). Community structure and species diversity of hermatypic corals at Eilat, Red Sea. Marine Biology 13:100-123.

Madhupratap, M. and Haridas, P. (1990). Zooplankton, especially calanoid copepods, in the upper $1000 \mathrm{~m}$ of the south-east Arabian Sea. Journal of Plankton Research 12: 305 - 321.

Magurran, A. E. (1988). Ecological Diversity and Its Measurement. Chapmann and Hall, London.

Mantha, G.; Al-Sofyani, A. A.; Al-Aidaroos, A. M. and Crosby, M. P. (2019) Zooneuston and zooplankton abundance and diversity in relation to spatial and nycthemeral variations in the Gulf of Aqaba and northern Red Sea. Acta Oceanologica Sinica 38(12): 59-72.

Mazzocchi, M. G. and Ribera d'Alcala, M. (1995). Recurrent patterns in Zooplankton structure and succession in a variable coastal environment. ICES Journal of Marine Science 52: 679 - 691.

Michel, H. B.; Behbehani, M. and Herring, D. (1986a). Zooplankton of the western Arabian Gulf South of Kuwait waters. Kuwait Bulletin of Marine Science, KISR, Series No. 1435: 1-36.

Michel, H. B.; Behbehani, M.; Herring, D.; Arar, M.; Shoushani, M. and Brakoniecki, T. (1986b). Zooplankton diversity, Distribution and abundance in Kuwait waters. Kuwait Bulletin of Marine Science, KISR, Series No. 1433: 37 105. 
Mitra, A.; Castellani, C.; Gentleman, W. C.; Jónasdóttir, S. H.; Flynn, K. J. and

Bode, A. (2014a). Bridging the gap between marine biogeochemical and fisheries sciences; configuring the zooplankton link. Progress in Oceanography 129: 176199.

Mitra, A.; Flynn, K. J.; Burkholder, J. M.; Berge, T.; Calbet, A.; Raven, J. A. and Thingstad, F. (2014b). The role of mixotrophic protists in the biological carbon pump. Biogeosciences 11: 995-1005.

Mori, T. (1964). The Pelagic Copepoda from the Neighbouring Waters of Japan. The Soyo Company Inc, Tokyo, 150 pp.

Omori, M. and Ikeda, T. (1984). Methods in marine zooplankton ecology, John Wiley and Sons Inc., New York, 372 pp.

Paffenhöfer, G. A. (1984a). Food ingestion by the marine planktonic copepod Paracalanus in relation to abundance and size distribution of food. Marine Biology 80: 323-333.

Parsons, T. R.; Maita, Y. and Lalli, C. M. (1984). A Manual of Chemical and Biological Methods of Seawater Analysis. Pergamon Press, NewYork, 173 pp.

Pearman, J. K. and Irigoien, X. (2015) Assessment of zooplankton community composition along a depth profile in the central Red Sea. PLoS ONE 10(7): e0133487.

Poulet, S. A. (1978). Comparison between five coexisting species of marine copepods feeding Raymont J.E.G. 1983. Plankton and productivity of the oceans, Bergamon Press Ltd, Oxford, second Edition: 824 pp.

Razouls, C.; de Bovée, F.; Kouwenberg, J. and Desreumaux, N. (2015) Diversity and geographic distribution of marine planktonic copepods. https://www.copepodes. obs-banyuls.fr.

Schuhmacher, H. (1977). The initial phases in reef development, studied at artificial reef types off Eilat (Red Sea). Helgoländer wiss. Meeresunters 30: 400-411.

Schnack-Schiel, S.B.; Niehoff, B.; Hagen, W.; Bottger-Schnack, R.; Cornils, A.; Dowidar, M.M.; Pasternak, A.; Stambler, N.; Stubing, D. and Richter, C. (2008). Population dynamics and life strategies of Rhincalanus nasutus (Copepoda) at the onset of the spring bloom in the Gulf of Aqaba (Red Sea). Journal of Plankton Research 30 (6): 655-672.

Sewell, R. B. S. (1948). The free-swimming planktonic Copepoda. Geographical distribution. Sci. Rep. Murray Expedition 3: 317-592.

Stibor, H.; Vadstein, O.; Diehi, S.; Gelzleichter, A.; Hansen, T.; Hantzsche, F.; 
Katechakis, A.; Lippert, B. Løseth, K.; Peters, C.; Roederer, W. and Sandow, M. (2004). Copepods act as a switch between alternative trophic cascades in marine pelagic food webs. Ecol. Lett., 7, 321-328.

Strickland, J. D. H. and Parsons, T. R. (1972). A Practical Hand Book of Seawater Analysis. Fisheries Research Board of Canada Bulletin 157, 2nd Edition, 310 pp.

Sundt Hansen, L. and Olsen, Y. (2004). Copepods act as a switch between alternative trophic cascades in marine pelagic food webs. Ecology Letters 7:321 328.

Sullivan, K. B. (1980). In situ feeding behavior of Sagitta elegans and Eukrohnia hamata (Chaetognatha) in relation to the vertical distribution and abundance of prey at Ocean Station 'P'. Limnology and Oceanography 25: 317-326.

Tattersall, W.M. and Tattersall, O.S. (1951). The British Mysidacea. Ray Society, London, viii, $460 \mathrm{pp}$.

Turner, J. T. (2004). The importance of small planktonic copepods and their roles in pelagic marine food webs. Zoological Studies 43(2): 255-266.

Weikert, H. (1980a). On the plankton of the central Red Sea. A first synopsis of results obtained from the cruises MESEDA I and MESEDA IO. Symposium Coastal and Marine Environment of the Red Sea, Gulf of Aden and Tropical Western, Indian Ocean,Khartoum, 9 - 14 January 1980, Vol. III: 135 - 168.

Weikert, H. (1980b). The oxygen minimum layer in the Red Sea: Eco-logical implications of the zooplankton occurrence in the area of the Atlantis II Deep. Meeresforschung, 28: 1-9.

Weikert, H. (1982). The vertical distribution of zooplankton in relation to habitat zones in the area of the Atlantis II Deep, central Red Sea. Marine Ecology Progress Series 8:129-143.

Weikert, H. (1987). Plankton and the pelagic environment. In Edwards, A. J. and Head, S. M. (eds), Red Sea. Key Environments. Pergamon Press, Oxford, pp. 90-111.

Williams, R. and Conway, D. V. P. (1988) Vertical distribution and seasonal numerical abundance of the Calanidae in oceanic waters to the south-west of the British Isles. Hydrobiologia, 167/168: 259-266. 